\title{
PREVALENCE OF IRON DEFICIENCY ANAEMIA AMONG CHILDREN AGED 6 MONTHS-5 YEARS ADMITTED AT KBNTGH AND TO KNOW THE RATES OF PROPHYLACTIC IRON SUPPLEMENTATION, A ONE YEAR RETROSPECTIVE STUDY
}

\author{
Mujumdar V. G1, Siddaling Changty², Preethi Amarkhed ${ }^{3}$, Nabeel Nazeer $^{4}$, Harshvardhan $^{5}$ \\ ${ }^{1}$ Associate Professor, Department of Paediatrics, Khaja Banda Nawaz Institute of Medical Sciences, Gulbarga. \\ ${ }^{2}$ Professor \& HOD, Department of Paediatrics, Khaja Banda Nawaz Institute of Medical Sciences, Gulbarga. \\ ${ }^{3}$ Assistant Professor, Department of Paediatrics, Khaja Banda Nawaz Institute of Medical Sciences, Gulbarga. \\ ${ }^{4} J u n i o r$ Resident, Department of Paediatrics, Khaja Banda Nawaz Institute of Medical Sciences, Gulbarga. \\ 5Junior Resident, Department of Paediatrics, Khaja Banda Nawaz Institute of Medical Sciences, Gulbarga.
}

\section{ABSTRACT}

The aim of this study was to know the prevalence of Iron Deficiency Anaemia (IDA) among chilsdren aged 6 months-5 years in KBNTGH (Khaja Bandanawaz Teaching and General Hospital attached to Khaja Bandanawaz Institute of Medical Sciences). The files of 1519 patients aged between 0-5 years, who were hospitalized to KBN Hospital Pediatrics Ward were reviewed. A total of 50 patients with anaemia (Haemoglobin: 9gm\%) consisting of 35 boys and 15 girls with the mean age of $16.59 \pm 1.68$ months were included into the study. The prevalence of IDA was 3.29\% (Boys: $4.23 \%$, girls: $2.1 \%$ ). Haemoglobin and haematocrit of these patients was analysed. Hemoglobim and hematocrit of children $>24$ months were significantly higher than those of the patients with the age of 6-12 months. Of the 28 patients who were older than 12 months, only $44 \%$ of them had received a full course of iron supplementation for 8 months. In conclusion, although prophylactic iron supplementation lowered the prevalences of IDA, receiving rates of iron supplementation were not adequate. While IDA is still a public health problem, prophylactic approaches should be carried out more effectively.

\section{KEYWORDS}

Rates of prophylactic Iron supplementation-A 1-year Retrospective study Anemia, Iron deficiency, Supplementation.

HOW TO CITE THIS ARTICLE: Mujumdar V. G, Siddaling Changty. Preethi Amarkhed, Nabeel Nazeer, Harshvardhan. "Prevalence of Iron Deficiency Anaemia Among Children Aged 6 Months-5 Years Admitted at KBNTGH and to know the Rates of Prophylactic Iron Supplementation, a one-year Retrospective Study." Journal of Evolution of Medical and Dental Sciences 2015; Vol. 4, Issue 99, December 10; Page: 16473-16475, DOI: 10.14260/jemds/2015/2445

\section{INTRODUCTION}

Iron deficiency is the most common and widespread nutritional disorder in the world.[1] It is the only nutrient deficiency, which is also significantly prevalent in all industrialized nations. According to the data of the World Health Organisation (WHO), the prevalence of Iron Deficiency Anaemia (IDA) in industrialized countries and in nonindustrialized countries is $10 \%-20 \%$ and $50 \%-60 \%$, respectively.[2] Globally, the prevalence of IDA in preschoolage children (0.00-4.99 years) and school-age children is $47.4 \%$ and $25.4 \%$ respectively. ${ }^{[3]}$

Iron deficiency impairs the cognitive development of children from infancy through adolescence. It also damages immune mechanisms and is associated with increased morbidity rates. The importance of iron deficiency anaemia as a public health problem has been increasingly recognized by health authorities and policy makers. Although, efforts are targeted primarily to prevent iron deficiency, it is still the most common nutrient deficiency all over the world. [2]

Financial or Other, Competing Interest: None.

Submission 05-10-2015, Peer Review 06-10-2015,

Acceptance 28-10-2015, Published 10-12-2015.

Corresponding Author:

Dr. Mujumdar V. G,

D. No. 34, NGO's Colony,

Jewargi Road,

Kalaburagi.

E-mail: drmujundarvg@gmail.com

DOI:10.14260/jemds/2015/2445

\section{MATERIALS AND METHODS}

The files of 1519 patients who were hospitalized in KBN Hospital Pediatrics ward between July 2012 and December 2012 for an acute illness were reviewed retrospectively. Fifty patients were found to have the diagnosis of IDA.

If diagnosis of anaemia was noticed, further evaluations including the measurements of serum iron, Total IronBinding Capacity (TIBC) and ferritin were performed. When indicated vitamin B12, folic acid levels and haemoglobin (Hgb) electrophoresis were obtained to rule out other nutrient deficiencies and haemoglobinopathies that can cause anaemia.

The patients included into the study were divided into 3 groups according to age: Group 1: 6-12 months, Group 2: 1224 months, and Group 3: $>24$ months. WHO Hgb thresholds were used to identify patients as anaemic $(\mathrm{Hgb}<11 \mathrm{~g} / \mathrm{dL}$ for patients $6-59$ months old, $\mathrm{Hgb}<11.5$ for patients $>59$ month old). IDA was defined as $\mathrm{Hgb}$ values less than WHO thresholds with the presence of two or more of the following parameters; Mean Corpuscular Volume (MCV) less than $70 \mathrm{fL}$, serum ferritin below $30 \mathrm{mcg} / \mathrm{L}$, and Transferrin Saturation (TSAT) less than $16 \%{ }^{[5,6]}$ Patients having chronic illness, hematologic diseases and thalassemia traits or receiving any chronic medication were not enrolled into the study. The variables examined in the study were Hgb, haematocrit (Hct), MCV, Mean Corpuscular Haemoglobin (MCH), Mean Corpuscular Haemoglobin Concentration (MCHC), Red Blood Cell (RBC), Red Cell Distribution Width (RDW), White Blood Cell (WBC), Platelet (Plt), iron, TIBC, TSAT, and ferritin levels of the patients. 


\section{STATISTICAL ANALYSIS}

The statistical analysis was carried out using the SPSS 15.0 statistical software package for Windows. Descriptive statistics of continuous variables were expressed as mean \pm standard deviation (sd). Independent samples-test was used to compare the mean values of the groups. MannWhitney test was used for normally distributed variables (Iron and TSAT). When comparing the means of more than two groups, one-way ANOVA and Kruskal-Wallis test were conducted. If there was difference between groups, Tukey's test was performed to compare between the groups was considered as significance level.

\section{RESULTS}

A total of 50 patients were included into the study (35 Boys and 15 Girls). The age range of the patients was from 6 months to 80 months (Mean age 16,59 $\pm 1,68$ months). Mean age for boys and girls was $14,87 \pm 1,41$ and $20,56 \pm 4,51$ months respectively.

Among a total of 1519 hospitalized patients, the prevalence of IDA was 3.29\% (Boys: $4.23 \%$, Girls: $2.1 \%$ ). Mean values (Mean \pm sd) of Hgb, Hct, MCV, MCH, MCHC, RBC, RDW, WBC, Plt, iron, TIBC, ferritin, and TSAT according to sex are given in Table 1 . There was no significant difference between girls and boys according to the variables except WBC. WBC levels of girls were significantly higher.

\section{DISCUSSION}

Iron deficiency is the most widespread and common nutritional disorder in the world in spite of the efforts to decrease the frequency. The prevalence varies in different parts of the world with higher rates in the developing countries. ${ }^{[5,7]}$ The results of studies from different cases in KBNTGH, Kalaburagi also showed that iron deficiency is the most important cause of anaemia. WHO recommends prophylactic supplementation of iron at a dosage of $2 \mathrm{mg} / \mathrm{kg} /$ day to all children between 6 and 23 months of age, especially where the diet does not include fortified foods or prevalence of anaemia in children approximately 1 year of age is severe. ${ }^{[2]}$ The low prevalence examined in our study may suggest that prophylactic iron supplementation has gradually increased. From the finding that the Hgb levels of patients aged 6-24 months were significantly lower than those of the age-appropriate thresholds, it can be considered that extension of prophylactic iron supplementation duration to 24 months might be more favorable.

Ferritin is an intracellular hollow protein shell composed of 24 subunits surrounding an iron core that may contain as many as 4000-4500 iron atoms. In the body, small amounts of ferritin are secreted into the plasma. The concentration of this plasma ferritin is positively correlated with the size of the total body iron stores in the absence of inflammation. Low serum ferritin values reflects depleted iron stores.[12] Ferritin levels, in contrast to Hgb, are not affected by residential elevation above sea level or smoking behaviour. However, ferritin is a positive acute phase response protein, whereby concentrations increase during an inflammatory disease or subclinical infection. This makes the interpretation of normal or high serum ferritin values difficult in areas of widespread infection or inflammation. ${ }^{[2]}$ The cut-off values of ferritin were revised in 1993 and it was reported that ferritin levels $<12 \mu \mathrm{g} / \mathrm{L}$ under 5 years of age,
$<15 \mu \mathrm{g} / \mathrm{L}$ above 5 years of age and $<30 \mu \mathrm{g} / \mathrm{L}$ in the presence of infection reflect the depleted iron stores.[12] In the study of Phiri conducted on patients with severe anaemia in a high infection pressured area, they found mean ferritin levels to be $729.2 \mu \mathrm{g} / \mathrm{L}$ and suggested that it was necessary to change the cut-off limit of ferritin from 30 to $273 \mu \mathrm{g} / \mathrm{L}$ in order to improve its diagnostic efficiency. The mean ferritin level of our patients was $30.71 \pm 4.58 \mu \mathrm{g} / \mathrm{L}$ (min.: 2.4 ; max.: 179.4); $34 \%$ of our subjects had a ferritin level above $30 \mathrm{mcg} / \mathrm{L}$ with other parameters indicating IDA. All of these subjects had an accompanying inflammatory disease.

Anaemia is a late manifestation of iron deficiency and iron deficiency without anaemia is even more widespread. If subtle effects of iron deficiency in infancy lay the ground for later problems in cognitive and behavioral functioning, then a large unrecognized population of children could be at risk due to perinatal iron deficiency, a nutritional problem that can be prevented or treated. Consequences of IDA during childhood include growth retardation, reduced school achievement, impaired motor and cognitive development, and increased morbidity from infections including especially diarrhea and acute respiratory infections. ${ }^{[2]}$ Specifically, iron deficiency can lead to deficits in memory and behavioural regulation as iron is required to make neurotransmitters such as dopamine, epinephrine and serotonin while impaired myelination contributes to deficits in motor function. Some of these impairments are thought to be irreversible if they occur at an early age and the consequences may continue even after treatment, reinforcing the importance of prevention.

\section{CONCLUSIONS}

In conclusion, although prophylactic iron supplementation lowered the prevalences of IDA, IDA is still a public health problem throughout the world. Iron deficiency impairs the cognitive development of children from infancy through adolescence. Therefore, prophylactic approaches should be carried out more effectively. It can be considered that extension of prophylactic iron supplementation duration to 24 months might be more favorable in our country. Because ferritin levels are increased during inflammatory processes, the cut-off levels should be reevaluated.

\section{REFERENCES}

1. DeMaeyer E and Adiels-Tegman M. "The prevalence of anaemia in the world," World Health Statistics Quarterly, vol. 38, no. 3, pp. 302-316, 1985. View at Google Scholar • View at Scopus.

2. World Health Organisation, Iron Deficiency Anaemia Assessment, Prevention and Control. A Guide for Programme Managers, WHO, 2001.

3. World Health Organisation, Worldwide Prevalence of Anaemia 1993-2005, WHO Global Database on Anaemia, WHO, 2008.

4. Turkish Ministry of Health, The Report of the Study of Iron Usage among 12-23 Month-Old Children, Turkish Ministry of Health, Ankara, Turkey, 2009.

5. Lerner NB and Sills R, "Iron deficiency anemia," in Nelson Textbook of Pediatrics, Kliegman RM, Stanton BF, J St Geme, Schor N and Behrman RE, Eds., pp. 16551658, Elsevier Saunders, Philadelphia, PA, USA, 19th edition, 2011. View at Google Scholar. 
6. Male C, Persson LÅ, Freeman V, Guerra A, Van't Hof MA and Haschke F. "Prevalence of iron deficiency in 12months-old infants from 11 European areas and influence of dietary factors on iron status (Euro-Growth study)," ActaPaediatrica, vol. 90, no. 5, pp. 492-498, 2001. View at Google Scholar ·View at Scopus.

7. World Health Organisation, Preventing and Controlling Iron Deficiency Anaemia through Primary Health Care, A Guide for Health Administrators and Programme Managers, WHO, Geneva, Switzerland, 1989.

8. Koçak R, Alparslan ZN, Ağridağ G, Başlamisli F, Aksungur PD and Koltaş S. "The frequency of anaemia, iron deficiency, hemoglobin $S$ and beta thalassemia in the South of Turkey," European Journal of Epidemiology, vol. 11, no. 2, pp. 181-184, 1995. View at Publisher • View at Google Scholar.

9. Aydınok Y, Öztop Ş, Nişli G, Kavaklı K and Çetingül N. "Percentile norms and curves for hematological values in Turkish adolescents," Turkish Journal of Haematology, vol. 15, pp. 169-173, 1998. View at Google Scholar.
10. Kilinç M, Yüregir GT and Ekerbiçer H. "Anaemia and iron-deficiency anaemia in South-East Anatolia," European Journal of Haematology, vol. 69, no. 5-6, pp. 280-283, 2002. View at Publisher -View at Google Scholar.

11. Cetinkaya F, Yildirmak Y and Kutluk G. "Severe irondeficiency anemia among hospitalized young children in an urban hospital," Pediatric Hematology and Oncology, vol. 22, no. 1, pp. 77-81, 2005. View at Publisher · View at Google Scholar • View at Scopus.

12. World Health Organisation, Serum Ferritin Concentrations for the Assessment of Iron Status and Iron Deficiency in Populations, Vitamin and Mineral Nutrition Information System, WHO, Geneva, Sw.

\begin{tabular}{|c|c|c|c|}
\hline & BOYS (n=35) & GIRLS (n=15) & P \\
\hline $\mathrm{Hgb}(\mathrm{g} / \mathrm{dl})$ & $9.77 \pm 0.14$ & $9.69 \pm 0.34$ & $>0.05$ \\
\hline $\mathrm{Hct}(\%)$ & $31.03 \pm 0.48$ & $31.37 \pm 0.83$ & $>0.05$ \\
\hline $\mathrm{MCV}(\mathrm{fL})$ & $6496 \pm 0.87$ & $64.13 \pm 1.82$ & $>0.05$ \\
\hline $\mathrm{MCH}(\mathrm{pg})$ & $20.50 \pm 0.39$ & $19.79 \pm 0.73$ & $>0.05$ \\
\hline $\mathrm{MCHC}(\mathrm{gr} / \mathrm{dL})$ & $31.48 \pm 0.25$ & $30.79 \pm 0.47$ & $>0.05$ \\
\hline $\mathrm{RBC}(\mathrm{M} / \mathrm{mL})$ & $4.81 \pm 0.10$ & $4.93 \pm 0.18$ & $>0.05$ \\
\hline $\mathrm{RDW}(\%)$ & $16.75 \pm 0.31$ & $17.36 \pm 0.57$ & $>0.05$ \\
\hline $\mathrm{WBC}\left(\mu \mathbf{L}^{-\mathbf{1}}\right)$ & $10.81 \pm 0.63$ & $13.75 \pm 1.56$ & $>0.05$ \\
\hline $\mathrm{PLT}\left(\mu \mathbf{L}^{-\mathbf{1}}\right)$ & $384742.85 \pm 22314.90$ & $408000.00 \pm 38686.28$ & $>0.05$ \\
\hline $\mathrm{Iron}(\mu \mathrm{g} / \mathrm{dL})$ & $29.17 \pm 4.88$ & $18.86 \pm 2.71$ & $>0.05$ \\
\hline TIBC $(\mu \mathrm{g} / \mathrm{dL})$ & $339.14 \pm 18.48$ & $345.73 \pm 16.63$ & $>0.05$ \\
\hline Ferritin $(\mu \mathrm{g} / \mathrm{L})$ & $29.43 \pm 5.66$ & $33.68 \pm 7.87$ & \\
\hline TSAT $(\%)$ & $15.93 \pm 6.65$ & $5.40 \pm 0.72$ & \\
\hline
\end{tabular}

RDW levels were significantly higher in patients aged between 13 and 24 months than the patients $>24$ months. With respect to age, the number of the subjects in Group 1, Group 2 and Group 3 was 22, 21 and 7, respectively. Hgb levels were gradually increasing with age and this association was statistically significant (Table 2). Hgb and Hct of the patients $>24$ months old were significantly higher than those of the patients with the age of 6-12 months. Additionally, when mean Hgb levels were compared with the age-appropriate $\mathrm{Hgb}$ thresholds, the levels of Groups 1 and 2 were significantly lower than those of the thresholds.

\begin{tabular}{|c|c|c|c|c|c|}
\hline Age & N & Hgb (g/dL) & MCV (fL) & Ferritin ( $\mathbf{\mu g} / \mathbf{L})$ & TSAT (\%) \\
\hline 6-12 months & 22 & $9.40 \pm 0.15$ & $65.20 \pm 1.17$ & $25.44 \pm 4.25$ & $10.79 \pm 3.20$ \\
\hline 12-24 months & 21 & $9.81 \pm 0.26$ & $64.20 \pm 1.17$ & $29.94 \pm 8.55$ & $6.04 \pm 0.67$ \\
\hline > 24 months & 7 & $10.61 \pm 0.22$ & $64.72 \pm 3.01$ & $49.54 \pm 14.83$ & $39.19 \pm 32.06$ \\
\hline \multicolumn{7}{|c|}{ Table 2: IDA Parameters of the Patients with respect to Age } \\
\hline
\end{tabular}

Although prophylactic iron supplementation is recommended to be used from 4 months until 1 year, there were patients who never received or received only one bottle (A usage of nearly 1 month) of iron supplementation. Of the 28 patients older than 12 months, only 28\% ( 8 patients; 6 boys, 2 girls) received full course of iron supplementation for 8 months, where 28\% ( 8 patients; 7 boys 1 girl) of them receive it only for 1 month. The rest $44 \%$ did not receive iron supplementation despite the recommendations of their family physicians. Although rate of prophylactic iron supplementation use was significantly decreasing with age, there was no significant difference among variables according to receiving iron supplementation. 